

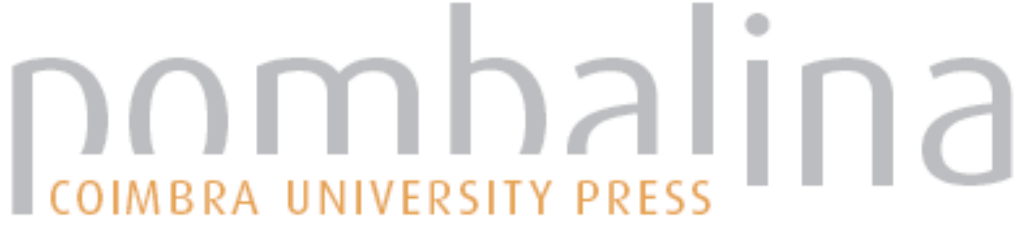

\section{O poder local nos finais do Antigo Regime}
Autor(es):
Sousa, Fernando de
Publicado por: Imprensa da Universidade de Coimbra; CEFA
URL
persistente:
URI:http://hdl.handle.net/10316.2/32471
DOI:
DOI:http://dx.doi.org/10.14195/978-989-26-0439-8_8

Accessed : $\quad$ 26-Apr-2023 14:54:41

A navegação consulta e descarregamento dos títulos inseridos nas Bibliotecas Digitais UC Digitalis, UC Pombalina e UC Impactum, pressupõem a aceitação plena e sem reservas dos Termos e Condições de Uso destas Bibliotecas Digitais, disponíveis em https://digitalis.uc.pt/pt-pt/termos.

Conforme exposto nos referidos Termos e Condições de Uso, o descarregamento de títulos de acesso restrito requer uma licença válida de autorização devendo o utilizador aceder ao(s) documento(s) a partir de um endereço de IP da instituição detentora da supramencionada licença.

Ao utilizador é apenas permitido o descarregamento para uso pessoal, pelo que o emprego do(s) título(s) descarregado(s) para outro fim, designadamente comercial, carece de autorização do respetivo autor ou editor da obra.

Na medida em que todas as obras da UC Digitalis se encontram protegidas pelo Código do Direito de Autor e Direitos Conexos e demais legislação aplicável, toda a cópia, parcial ou total, deste documento, nos casos em que é legalmente admitida, deverá conter ou fazer-se acompanhar por este aviso.

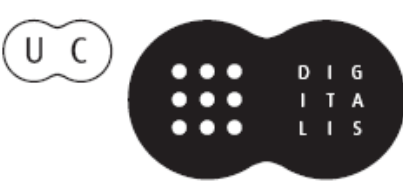


FERNANDO TAVEIRA DA FONSECA

\section{Coordenação}

O poder local em tempo de

Globalização

uma história

e um futuro

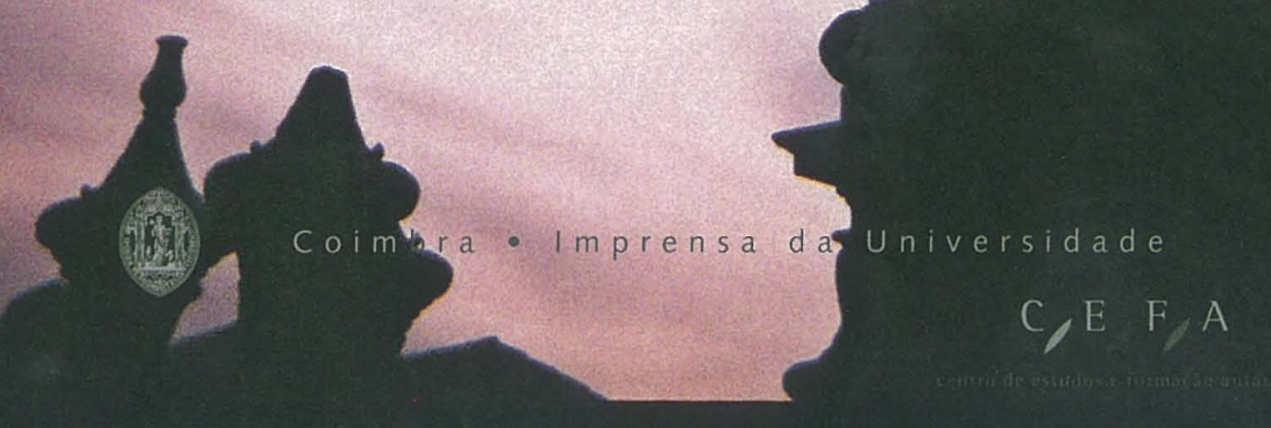


(Página deixada propositadamente em branco) 


\section{FERNANDO TAVEIRA DA FONSECA}

Coordenação

$\mathrm{O}$

poder local

em tempo

de

Globalização

uma história

e um futuro

Coimbra - Imprensa da Universidade

$C, E, F / A$ 
COORDENAÇÃo EDITORIAL

Imprensa da Universidade de Coimbra

CONCEPÇÃo GRÁfICA

António Barros

PAGINAÇÃo

António Resende

[Universidade de Coimbra]

EXECUÇÃo GRÁFICA

G.C. - Gráfica de Coimbra, Lda.

Palheira - Assafarge - Apart. 3068

3001-453 Coimbra Codex

\section{ISBN}

972-8704-32-1 (IUC)

972-8809-11-5 (CEFA)

DEPÓSITO LEGAL

229953/05

(c) JUNHO 2005, IMPRENSA DA UNIVERSIDADE DE COIMBRA 
Fernando de Sousa

Universidade do Porto

\title{
O Poder Local nos finais do ANTigo Regime
}

\author{
«Eu creio que a primeira origem da nossa desgraça é a seguinte \\ - impor continuamente o maior peso dos encargos públicos \\ sobre a classe mais pobre dos cidadãos.» \\ (Lourenço Guimarães Moreira, O espirito da economia politica \\ naturalizado em Portugal... 1781)
}

\section{Introdução}

Embora o Portugal de finais do Antigo Regime tenha sido objecto, na última década, de um significativo conjunto de estudos, que contribuiu consideravelmente para um melhor conhecimento dessa época de transição, a verdade é que existem ainda numerosas áreas que continuam a aguardar pelo seu investigador.

No campo social, por exemplo, unanimemente se proclama a situação miserável do povo, principalmente do lavrador, sobrecarregado com tributos de todo o género; mas não se conhecem estes, a não ser de um modo impreciso, ou apenas enunciando os mais importantes, esquecendo a forçosa diversidade regional, o diferente regime de propriedade, o tipo de contrato de exploração da terra e, o que não é de menosprezar, a brandura ou a dureza do proprietário, rendeiro ou arrematante, na cobrança dos direitos, impostos e dízimos.

Não bastará, contudo, indicar os encargos, contribuições ou impostos, directos ou indirectos, que recaíam sobre a população, para se ter uma ideia do seu nível e qualidade de vida. Para além da enunciação daqueles impostos que, dentro do espaço português, podemos classificar como gerais, extensivos a toda a população não privilegiada — os privilégios e as «isenções» constituem o traço mais característico e intrínseco da sociedade do Antigo Regime, os quais, lamentavelmente, persistiram, ainda que consideravelmente atenuados, até aos nossos dias —, importa ainda conhecer as violências exercidas pela administração regional e local que, nas comarcas e concelhos, não obstante as leis gerais do Reino, se tornavam, não raras vezes, ainda mais insuportáveis que as contribuições régias, eclesiásticas e senhoriais. 
Enfim, para se conhecer a verdadeira situação do povo nos finais do Antigo Regime, há que ter em conta a diversidade das formas assumidas pelo poder regional e pelo poder local, a sobreposição e rivalidade de poderes e funções entre os diferentes órgãos e magistraturas e, o que é da maior importância, o modo como, por um lado, corregedores e provedores nas respectivas comarcas e provedorias e, por outro lado, juízes de fora, juízes ordinários e vereadores nos diferentes concelhos, exerciam as suas funções, sob o pretexto de cumprirem as leis gerais e os acórdãos e posturas municipais.

São poucos os estudos que procuram responder à extensa e complexa problemática aqui esboçada, que se prende com as funções e sobretudo o modo como os magistrados territoriais - corregedores e provedores - e as câmaras municipais as exerciam.

De que forma era administrada a justiça nesse mundo rural, crente e analfabeto, que constituía Portugal? Como é que as câmaras exerciam os seus poderes? Qual a natureza e modalidades que os abusos, violências e arbitrariedades revestiam? Que graus de conflitualidade, resistência e revolta se detectavam na sociedade, em função da opressão e das injustiças cometidas pelos magistrados e pelas câmaras? Até que ponto a rivalidade existente entre corregedores e provedores traduzia a emulação ou competição entre as Secretarias de Estado e outros órgãos do Poder Central, ou a rivalidade entre quem retirava mais benefícios no exercício das suas funções?

Só poderemos responder a estas questões e ter uma leitura rigorosa das mesmas, a nível nacional, quando surgirem estudos locais e regionais orientados para esta problemática, a partir de numerosas fontes manuscritas que continuam por estudar.

Para já, aqui fica o nosso contributo, baseado nas fontes manuscritas e impressas de que dispomos quanto à comarca de Leiria, no centro de Portugal, a partir do trabalho de Guimarães Moreira, à comarca ou ouvidoria de Beja, no sul do País, graças à memória de Gervásio Pais, à província da Estremadura, através da memória de Bacelar Chichorro e finalmente, à comarca de Moncorvo, no norte de Portugal, a partir dos escritos de José António de Sá, corregedor da comarca de Moncorvo entre 1788-1794, e cuja acção e memórias estão a ser estudadas por nós.

\section{Guimarães Moreira e a comarca de Leiria}

A primeira denúncia e sem dúvida das mais vigorosas - que permaneceu no remanso dos manuscritos da Academia das Ciências até ao nosso tempo e em boa hora tornada pública por Luís Cardoso - é de Guimarães Moreira, corregedor da comarca de Leiria, em 1781. 
Segundo ele, a primeira origem da nossa desgraça era a de fazer recair o maior peso dos encargos públicos sobre a classe social mais pobre dos cidadãos, isto é, sobre os que viviam do seu trabalho e indústria, como os pequenos proprietários das terras, os pequenos lavradores rendeiros e os oficiais mecânicos.

As «castas de vexações» e opressões públicas que se faziam ao «miserável povo», principalmente ao povo lavrador, eram muito mais violentas e pesadas que todos os tributos que se cobravam. Qual era a providência, regulamento ou costume - interroga-se ele - que, bem ou mal entendido ou praticado, não oprimia ou vexava o povo, muito especialmente, os agricultores?

Nas eleições para a governança das vilas, quando tais cargos obrigavam a grandes despesas, os ricos, fundamentados nos privilégios que detinham, logo se escusavam, obrigando os mais pobres a servir os cargos municipais e a gastar o que não podiam. E o mesmo acontecia nas eleições dos louvados e cobradores dos tributos, nas restantes eleições que se faziam nas câmaras, e nas nomeações dos repartidores ou lançadores da décima e da sisa.

Nas correições dos vereadores e almotacés, as multas e condenações cobradas arbitrariamente, as fintas dos concelhos, os encargos das coudelarias, as prisões e violências que se seguiam a tudo isto, constituíam outros tantos modos de onerar e «vexar o povo lavrador».

Outro meio geral de oprimir o povo dizia respeito ao modo como se faziam ou consertavam os caminhos públicos em Portugal. As violências praticadas eram «verdadeiramente enormes», uma «verdadeira guerra civil declarada aos homens mais úteis do Estado», com uma multidão de esbirros a assaltarem os campos para neles recrutarem violentamente os lavradores destinados à calçada da vila ou ao conserto de estradas, não recebendo estes qualquer salário pelo seu trabalho. E se faltavam, logo os almotacés impunham aos miseráveis duras condenações - chegavam a ir a 500 réis - , seguindo-se as custas para a sua cobrança, as penhoras, os caminheiros, as prisões, etc.

Além destas vexações, gerais a todo o Reino - continua Guimarães Moreira -, existiam outras «particulares a cada vila ou cidade», como as «festas e funções de touros», que oneravam mais fortemente os lavradores, em muitas terras, que a décima ou a sisa.

Tudo isto praticado à vista e à face de todos, sob a autorização do costume, esse velho tirano que governava «tão imperiosamente o mundo! »

O mal só poderia ter remédio através de uma providência geral que proibisse às câmaras e almotacés «todo o exercício da jurisdição económica». As câmaras deveriam ser, apenas, «um corpo representativo da cidade ou vila, para requerer e procurar tudo o que pertencesse ao público». 
O aumento da indústria e agricultura era totalmente incompatível com as taxas que os almotacés impunham, com as propinas que levavam aos vendedores e com todo o conjunto de restrições e proibições exigidas.

As posturas dos concelhos, de que os almotacés eram executores, autorizavam «estas e outras inúmeras violências, que sem propósito nem fim» vexavam e oprimiam os povos.

Por outro lado, a proibição de se trabalhar sem licença das câmaras, assim como a exigência e o registo oneroso de todos as cartas de exame dos ofícios mecânicos, eram «abusos enormes, formados pelo espírito de monopólio» vindo dos séculos passados.

Apesar de em todas as vilas haver vereadores, procurador do concelho e escrivão da câmara, não havia uma só pessoa que promovesse o trabalho útil.

É certo que os corregedores tinham o poder de anular as posturas que não cumprissem as formalidades devidas e de dar conta ao soberano daquelas que eram prejudiciais ao bem público. Mas nem todos os corregedores das comarcas dominavam a economia política, ou se preocupavam com tais matérias. E por outro lado, em matéria de bem público, não havia pontos de vista unânimes entre os magistrados. ${ }^{(1)}$

\section{Gervásio Pais e a ouvidoria de Beja}

Gervásio Pais, na sequência da provisão de 6 de Agosto de 1788, na sua excelente memória quanto às observações e exames feitos sobre as causas do atraso e ruína da agricultura e povoação do Alentejo, especialmente nas terras da comarca de Beja, vai legar-nos um impressivo testemunho quanto aos abusos das câmaras.

Segundo ele, nas câmaras, o favor e o interesse dominavam os pelouros e as pautas, e o vereador era «pensionário do público». «Quem revolve o fundo da administração das câmaras só vê torpezas, o amor do bem público apenas aparece nos tempos que passaram, e nas ruínas de obras públicas que estão acusando a indolência actual».

No que diz respeito às rendas dos concelhos e sua aplicação, demonstra que, na comarca de Beja, os rendimentos daqueles consumiam-se, na sua maior parte, em «ordinárias e propinas dos oficiais da governança, ministros das justiças e salários de caminheiros» (Quadro n. ${ }^{\circ} 1$ ).

\footnotetext{
' (1) Lourenço José de Guimarães Moreira, O espírito da economia política naturalizado em Portugal e principalmente em Leiria, publicado por José Luís Cardoso, Memórias Económicas inéditas (17801808), Lisboa, 1987.
} 


\section{Quadro n. 1 - OUVIDORIA DE BEJA}

Aplicação das rendas da câmara de Moura (1787-1788)

Receita média anual 900000 a 1000000 réis

Despesa dos caminheiros da sede da comarca 25043 réis

Despesa dos caminheiros da seda da provedoria 38930 réis

Despesa com as propinas do ouvidor, juiz de fora,

Vereadores e procurador, escrivão da câmara e outros oficiais

730578 réis

Aplicação das rendas da câmara de Serpa (1787-1788)

Receita média anual

1000000 réis

Despesa com as propinas do ouvidor, juiz de fora,

Vereadores e procurador, escrivão da câmara e outros oficiais

784074 réis

Aplicação das rendas da câmara de Beja (1787)

Receita em 1787

754283 réis

Despesa aprovada pela Provedoria

803898 réis

Despesa efectuada com o pagamento de propinas

729056 réis

Depois de D. João $\mathrm{V}$, as provisões para mais e maiores propinas, passaram a ser «abusiva e arbitrariamente» interpretadas em proveito próprio. O ouvidor, juiz de fora, vereadores e procurador do concelho levavam, «por costume», propinas para lutos e luminárias, pela morte, nascimento ou casamento dos príncipes e soberanos, mesmo quando as despesas eram superiores às receitas. Todas as câmaras da comarca registavam "copiosíssimos foros de galinhas», que nunca entravam nos livros das receitas, não retirando os provedores a terça real de tais rendimentos, que eram repartidos pelos oficiais e juízes, não havendo qualquer título para tal.

Os escrivães das câmaras, além das ordinárias e propinas estabelecidas, levavam salários por fazerem os registos à custa dos concelhos, assim como de passar mandados, quando tal Ihes competia pelas suas funções.

Todas as propinas e despesas ordinárias impostas nos rendimentos dos concelhos só podiam ser cobradas havendo sobras das rendas, depois de feitas as despesas 
necessárias com as obras públicas. Só que tal não acontecia. As «escandalosíssimas» propinas, que cresciam tanto mais quanto maiores eram as rendas, acabavam por deixar os concelhos endividados. As câmaras — desabafa Gervásio Pais — «só servem para património de quem entra nelas».

Em virtude de tão "abusiva aplicação» das rendas concelhias, as estradas, ruas, calçadas e pontes da ouvidoria de Beja estavam reduzidas a "barrancos e ruínas», «passos escabrosos» e a «atoleiros». (2)

\section{Bacelar Chichorro e a província da Estremadura}

Em 1795, Bacelar Chicorro, na esteira de Guimarães Moreira, que cita e segue, vai chamar a atenção, mais desenvolvidamente, para os obstáculos que se opunham, na Estremadura, ao «adiantamento dos ramos da indústria», para os «tributos mal assentados e extorsões cometidas pelos seus exactores», para a «ilimitada jurisdição das câmaras e seus abusos», e para os gravames, "que não sendo régios, vexavam e oprimiam aos vassalos mais que todos os tributos, e contribuições públicas»; encargos dos concelhos «e outros mais opressivos, sem terem princípio em ordem, ou mandado algum régio».

Indica a execução arbitrária das posturas entregue a um rendeiro; o grande número de coimas, a maior parte falsas; as inúmeras licenças que, obrigatoriamente, se tiravam na câmara, desde limpar as árvores, a ter lenha à porta, fazer uma estrumeira, a concertarem e levantarem valados, muros e tapumes, até à entrega, por cada fogo, de 5 cabeças de pardais ao escrivão da câmara e conclui que «um vassalo pobre, mas útil, pela sua vida sempre ocupada, paga todos os anos três, quatro, e seis mil réis de custas, licenças e condenações, quando não chega a pagar 200 réis de contribuições régias. Isto parece incrível, mas é tudo uma pura verdade de que eu tenho sido muitas vezes testemunha, e em circunstâncias, que me têm enternecido».

Estas opressões - garante Chichorro - , eram autorizadas por diversas resolu154 ções régias, garantindo as coimas e "corridas» dos almotacés e oficiais da câmara, sem que em tempo algum se averiguasse da bondade da legislação económica por onde se regulavam as penas e os delitos de semelhante ordem. Tais resoluções tinham feito "os seus processos duros e privilegiados», estabelecendo que não houvesse embargos às sentenças das coimas e que se não concedesse apelação sem

(2) Gervásio de Almeida Pais, Observaçoens e exames feitos sobre as cauzas do atrazamento e ruina da agricultura e povoação na provincia do Alentejo, especialmente nas terras da comarca de Beja, onde os abuzos são muito similhantes aos que se practicão nas outras commarcas da mesma provincia (1789), ms. de biblioteca particular. 
depósito da quantia em causa, desembolso esse muito superior às posses do apelante, o qual, obrigado, assim, a ceder à violência, logo tratava de acomodar o rendeiro ou fiscal que o demandava.

Sofriam ainda os pobres muitas outras opressões, nomeadamente o abuso que obrigava gratuitamente os povos a trabalhar na abertura e reparação das calçadas e caminhos - os lavradores, fornecendo com os seus carros, "tantas carradas de pedra e os braceiros um dia de trabalho» - , sem que qualquer lei fundamentasse tal vexação; as portagens que em certas feiras se pagavam de todas bestas e gados que a ela ocorriam e que chegavam a importar em 80 réis por cabeça; e as taxas com que os almotacés, em seu interesse, iludindo a lei «por um costume inalterável», oneravam o pão, vinho e azeite.

Só a gente do campo era vítima de tais opressões, uma vez que os nobres e «os ricos da governança da terra» sempre se livravam de tais abusos, não havendo, para eles, posturas ou licenças das câmaras. Opressões e vexações - conclui Bacelar Chichorro - mais intensas nas terras dos juízes de fora, não só porque a lei aí tinha «execução mais viva», mas também porque, originando aquelas grandes lucros a tais ministros e seus escrivães, estes tinham todo o cuidado em não deixar afrouxar semelhantes determinações. (3) $^{-}$

\section{O exercício do poder local na comarca de Moncorvo}

José António de Sá, numa extensa memória por nós publicada, dá-nos conta, com um rigor inultrapassado, do «despotismo municipal», dos «males» que as câmaras praticavam aos «vassalos» do rei, principalmente aos lavradores, abusando do seu regimento com nítida transgressão das leis.

As câmaras, segundo José António de Sá, corregedor da comarca de Moncorvo na última década do século XVIII, tinham sido instituídas com três objectivos utilíssimos e necessários:

- administrar economicamente a república através dos seus acórdãos e posturas;

- zelar pelo património do concelho, de que se retirava a terça real;

(3) Bacelar Chichorro, Memoria economica politica da provincia da Estremadura. Traçada sobre as instrucções regias de 17 de Janeiro de 1793, publicada por Moses Bensabat Amzalak, com o título de A Memoria economica politica da provincia da Estremadura, Lisboa, 1943. 
- promover o bem público do concelho.

Ora, as câmaras, não só tinham postergado os fins do seu «destino», como, interpretando arbitrariamente as leis em vigor, serviam-se delas para imporem as maiores violências e abusos, locupletando-se com os bens alheios e causando danos irreparáveis aos "fiéis vassalos», abusos e violências que se revelavam ainda mais graves nos municípios presididos pelos juízes de fora do que naqueles que eram governados pelos juízes ordinários.

Os acórdãos e posturas municipais - continua Sá - que tinham por finalidade o «bom regime da república, o interesse, o bem comum dos povos», em vez da felicidade, promoviam a «desgraça da república», reduzindo os seus concidadãos à opressão, à miséria e ao abatimento.

O «miserável e aflito povo» jazia debaixo de "condenações violentíssimas e continuadas», submetido ao "capricho contrário a toda a equidade». Sendo os «mais fracos» da república, eram aqueles que mais sofriam com as prepotências das câmaras.

Sá conclui que as câmaras, na comarca de Moncorvo, governavam os concelhos «à maneira dos baxás da Turquia, sem lei, nem ordenação e sem regra».

Os exemplos que carreia são bem elucidativos do pesado juízo que profere, como vamos ver.

- O abusivo costume de as câmaras, a propósito de servidões, possessões, caminhos ou rocios do concelho indevidamente apropriados, levarem elevados e arbitrários salários - 800 réis para cada vereador e 1200 réis para o escrivão da câmara, em Mirandela —, à custa do lavrador ou lavradores que incorressem em tais casos, acontecendo que o valor de tais vistorias era muito superior ao valor do que tinha sido usurpado.

- A prática de os oficiais da câmara obrigarem uma pessoa de cada casa a assistir-lhes às reuniões, quando em vereação pelo concelho, mesmo fora dos lugares em que habitavam, sob pena de condenação.

- A obrigação estabelecida por numerosas câmaras de uma pessoa por cada casa participar na montaria anual, na qual nunca se matava qualquer lobo, e que servia, apenas, para condenações injustas, chegando ao ponto, como em Alfândega da Fé, de os oficiais da câmara não anunciarem o local em que se encontravam para iniciar aquela, aumentando, assim, ainda mais, este violento tributo. Estas montarias, como diziam os lavradores, eram apenas efectuadas às suas pessoas e bolsas. 
- A obrigação de uma pessoa de cada casa assistir a todas as procissões reais na sede do concelho, quer dentro da légua, a partir da vila, quer aos povos de fora da légua, muito particularmente, os juízes de vintena.

- O processo de eleição dos juízes de vintena, que recaía sobre os homens mais pobres e miseráveis, sendo obrigados a pagar o juramento que o juiz de fora Ihes dava, a tirar regimento que igualmente pagavam, sofrendo ainda condenações quando o valor das coimas que apresentavam era considerado reduzido pelas câmaras, ou quando não conseguiam cumprir as obrigações absurdas impostas por aquelas, apenas com o objectivo de cobrarem dinheiro, o que fazia do ofício de juiz de vintena «um insuportável ónus».

- A obrigação estabelecida pelas câmaras, de todos os oficiais mecânicos, incluindo mestres, taberneiros, tecedeiras, fiadeiras de seda, etc., tirarem cartas, aranzéis e regimentos dos seus ofícios, que custavam 7,8 e 10 tostões, sob pena de multas pesadas, que chegavam a ir para além de dois e três mil réis, exigindo, até, cartas de exame nos ofícios em que não existia qualquer juiz.

- As posturas ilegais efectuadas pelas câmaras e por mais quatro homens, regra geral, mancomunados com os oficiais daquelas, não ouvindo, assim, de acordo com a lei, o povo e os homens bons, só com o objectivo «apaixonado e interessado» de acumular condenações.

Em Monforte do Rio Livre, no livro dos acórdãos, determinava-se que todas as estradas públicas do concelho fossem reparadas em sete dias, sob pena de os juízes dos povos ou vinteneiros, em número de 40 , serem condenados, cada um, em dois mil réis, apenas com o objectivo de arrecadarem 80000 réis; que os juízes obrigassem certas pessoas a vender pão e vinho em todas as aldeias do concelho, quando as vendas só existiam em lugares importantes, de passagem pública; que os almotacés fizessem correição, sob pena de 6000 réis e de se thes colocar nos livros da governança, nota de infâmia. Tais acórdãos, assim como as condenações a que, directa ou indirectamente davam lugar, tinham feito «tal revolução nos povos», que pediram a sua anulação, em tumulto e com lágrimas, a Sá, na correição de 1788. As câmaras justificavam tais violências, não com o objectivo de castigarem as transgressões das posturas, mas com a necessidade de obterem rendimentos.

- As despesas abusivas e ilegítimas dos juízes de fora e oficiais das câmaras, à custa dos bens e rendimentos do concelho, de tal forma que estes constituíam 
"O património dos vereadores». A administração dos bens do concelho enfermava de graves irregularidades. Em Monforte, não havia tesoureiro do concelho, sendo todas as despesas a arbítrio do juiz de fora, o mesmo acontecendo em Mirandela. Em Mós, o rendimento dos logradouros do povo não entrava na arca do município, nem pagava terça real. Nas câmaras de Moncorvo, Mirandela, Freixo e outras, os membros das câmaras, pela assistência às procissões, levavam propinas ordinárias e extraordinárias, e de 5 moedas de ouro para cada membro, nas ocasiões faustas e infaustas da Casa Real.

- Os foros ilegais que as câmaras tinham estabelecido nas árvores plantadas nos baldios, de tal forma que nalguns concelhos eram exigidos mesmo após o desaparecimento das árvores. No concelho de Mirandela, havia mesmo um tombo destes foros, mandado fazer pelo provedor da comarca. No concelho de Carrazeda de Ansiães, a câmara mandava cortar as árvores de particulares existentes nos baldios, sempre que necessitava de madeiras para as obras públicas. E no concelho de Freixo, a câmara efectuava duras vistorias e condenações sobre os lavradores que tratavam as árvores que plantavam nos baldios.

O maior obstáculo que impedia na comarca de Moncorvo o desenvolvimento da agricultura e o bem-estar e felicidade dos povos eram, como diz Sá, as injustiças que as justiças faziam aos miseráveis lavradores.(4)

\section{Os magistrados territoriais e o poder local}

É evidente que muitos dos abusos, extorsões e violências praticados pelo poder local podiam ser limitados pelos corregedores e provedores, como fez José António de Sá, na comarca de Moncorvo, em finais de Setecentos. Só que tal não acontecia, a não ser excepcionalmente.

(4) Fernando de Sousa, A Memória dos abusos praticados na comarca de Moncorvo de José António de Sá (1790), separata da Revista da Faculdade de Letras da Universidade do Porto, série de História, vol. IV, Porto, 1974; Portugal nos fins do Antigo regime. Fontes para o seu estudo, separata da revista Bracara Augusta, t. XXXI, Braga, 1977; Uma descrição de Trás-os Montes por Jose António de Sá, separata da revista População e Sociedade, n. ${ }^{\circ}$, do CEPFAM — Centro de Estudos da População e Família, Porto, 1998; A Correição de Moncorvo em finais do século XVIII, separata da revista População e Sociedade, n. ${ }^{\circ}$, do CEPESE - Centro de Estudos da População, Economia e Sociedade, Porto, 2001 
Como diz António Hespanha, haveria, em finais do Antigo Regime, uma certa cumplicidade entre os magistrados territoriais e locais de nomeação régia, corregedores, provedores e juízes de fora, que teriam contribuído, não para o reforço do poder local, não para o fortalecimento do poder da Coroa, mas para proveito próprio (todos os ministros, justiças e oficiais das câmaras - exclama Gervásio Pais —, comiam «sem conta, peso, nem medida»), hipótese a explorar, mas que, a comprovar-se, ajudaria a explicar as poucas queixas levantadas contra e entre tais magistrados.

Neste caso, só as desinteligências, rivalidades ou conflitos entre corregedores, provedores ou juízes de fora é que permitiriam conhecer-se um pouco melhor a actuação arbitrária e abusiva de qualquer um destes magistrados.

Sabemos que, por vezes, esses conflitos ocorriam. Sabemos também que a sobreposição e justaposição de certas atribuições e jurisdições provocavam choques latentes e uma evidente rivalidade entre estes magistrados de nomeação régia, quer entre corregedores e provedores, quer entre provedores ou corregedores e juízes de fora. Mas a tendência do poder central, nestes casos, não era o apuramento da verdade até às últimas consequências, mas «contemporizar, pôr uma pedra em cima», não dando razão explícita a este ou aquele magistrado, outrossim, concluindo que ambos tinham ido longe de mais, anulando-se, deste modo, um ao outro.

Os exemplos conhecidos da literatura de finais do Antigo Regime, escassos, ou resultam de uma diligência especial, como a de Gervásio Pais, nomeado em 1788 para averiguar os abusos que concorriam para a ruína e agricultura do Alentejo, ou são muito vagos, generalistas, ou finalmente, assentam mais em razões de prestígio que em denúncias de abusos ou irregularidades praticadas por um destes magistrados quando entra em colisão com outro.

No que diz respeito ao Alentejo, mais concretamente, à ouvidoria de Beja, Gervásio Pais, em 1788, refere que muitas das rendas dos municípios eram dispendidas com aposentadorias «pagas a dinheiro» aos ministros e oficiais da comarca e não em espécie - lenha e louça — , como mandava a lei.

Os concelhos eram gravados com as despesas dos caminheiros enviados pela provedoria e ouvidoria da comarca, sobretudo nos registos de leis e ordens iguais, emanadas pelos tribunais e chancelaria-mor do Reino e dirigidas aos dois ministros, quando os provedores só deviam mandar fazer esses registos nas câmaras das terras dos donatários em que não entravam os corregedores e ouvidores em correição, pois a estes incumbia fazer registar as leis. Acrescia que, por provisão de 2 de Julho de 1730, registada nas câmaras, era proibido aos ministros e escrivães das comarcas levarem dos concelhos assinaturas pelas ordens que passavam para estes registos. $\mathrm{E}$ ainda que, por resolução de D. José, estava proibido utilizar caminheiros para tais registos, havendo correios da cabeça da comarca para as restantes vilas da mesma. 
Os provedores, nas suas revistas, a propósito das coimas e da guarda dos campos, regra geral, estavam "prevenidos e de má fé contra os incoimantes», fazendo-se «superiores à lei», desrespeitando os processos referidos pelas Ordenações, e absolvendo quem a lei condenava, por «favor, capricho e mais entendimento da lei».

Os provedores e seus oficiais - continua Gervásio Pais - nas contas ordinárias dos concelhos, em vez de 600 réis que a lei lhes concedia, levavam 15000 a 20000 réis. Pelo seu juízo e escrivão passavam mandados para si, sobre os tesoureiros das câmaras, sem individualizarem parcelas nem justificarem por que título o faziam.

O provedor de Beja, na sede da ouvidoria, regra geral, a exemplo do que se passava na câmara de Moura, praticava outros abusos:

- fazia e lançava despesas nos livros de contas do concelho pelo escrivão da provedoria, antes de as tomar;

- mandava pagar despesas, salários e emolumentos do seu Juízo e dos seus oficiais por mandados seus, sem qualquer autorização dos vereadores e juiz de fora, como exigia a lei;

- mandava rasgar todos os mandados e recibos das partes, no acto de tomar as contas, destruindo assim todos os documentos que legitimavam as despesas, as quais eram carregadas nos respectivos livros apenas no seu montante global, desconhecendo-se assim, a que título o provedor levava em cada correição, pelos seus mandados, 23596 réis e 4600 réis por tomar as contas, quando a lei só Ihe determinava 600 réis;

- levava aposentadorias a dinheiro, contra o que estava determinado por lei.

Por outro lado, os ouvidores de Beja, de cada câmara da comarca, levavam cerca de 100000 réis de propinas e ordinárias, de forma que, anualmente, só de propinas, faziam 500000 réis. "Tudo passa e se aprova» — conclui Gervásio Pais —, porque «todos se calam», provedores e oficiais da câmara(5) (Quadro n. ${ }^{\circ} 2$ ).

(5) Fernando de Sousa, A Correição de Moncorvo em finais do século XVIII, separata da revista População e Sociedade, n. ${ }^{\circ}$, do CEPESE - Centro de Estudos da População, Economia e Sociedade, Porto, 2001 


\section{Quadro.$^{\circ} 2$ - OUVIDORIA DE BEJA}

\section{Mapa das propinas pagas pela câmara de Beja (1787)}

$\begin{array}{lr} & \text { Ouvidor } \\ \text { Aposentadoria } & 40.000 \\ \text { Ordenado } & 10.000 \\ \text { Correição } & 8.000 \\ \text { Pautas } & 8.000 \\ \text { Vinte Procissões } & 20.000 \\ \text { Arroba e meia de cera } & 21.120 \\ \text { Um Carneiro } & 1.000 \\ \text { Um Porco } & 4.000 \\ \quad \text { Total } & \end{array}$

Juiz de Fora

Aposentadoria

40.000

rs.

Vinte Procissōes

20.000

Arroba e meia de cera

21.120

Uma Tocha

2.000

Uma Resma de papel

800

Um Carneiro

1.000

Um Porco

4.000

Pela feira

2.000

Total

90.920 réis

Três vereadores e procurador

Vinte Procissões

80.000

rs.

Seis arrobas de cera

84.480

Quatro Carneiros

4.000

Quatro Porcos

16.000

Um Selo para o vereador mais velho

2.000

4.000

Duas Tochas para os 2 vereadores mais velhos

Total

190.480 réis

Juiz de Orfãos

\section{Aposentadoria}

40.000

is.

Vinte Procissões

20.000

Arroba e meia de cera

21.120

Um Carneiro

1.000

Um Porco

4.000

Total

86.120 réis 
(Cont.)

Quadro n. ${ }^{\circ} 2$ - OUVIDORIA DE BEJA

Mapa das propinas pagas pela câmara de Beja (1787)

$\begin{array}{lrl} & \text { Escrivão da Câmara } & \\ \text { Vinte procissões } & 20.000 & \text { rs } . \\ \text { Arroba e meia de cera } & 21.120 & \text { rs. } \\ \text { Um Carneiro } & 1.000 \\ \text { Um Porco } & 4.000 \\ \text { Um Selo } & 1.000 \\ \text { Ordenado } & 6.000 \\ \text { Um pano para a mesa } & 8.000 \\ \text { Segundo Ordenado } & 12.000 \\ \text { Uma Escrivaninha } & 3.000 \\ \text { Por escrever na décima } & 30.000 \\ \text { Pelo assento dos enjeitados } & 11.000 \\ \text { Por escrever nas pautas } & 4.000 \\ \quad \text { Total } & \end{array}$

121.120 réis

Outros oficiais

Escrivão da Ouvidoria

2.000 is.

Escriväo da Ouvidoria

2.000

Meirinho da Ouvidoria

4.000

Porteiro da Ouvidoria

800

Porteiro da Câmara

12.000

Síndico

10.000

Médicos de Coimbra

36.030

Secretário da câmara de sua alteza

25.500

Aos dois porteiros do geral

8.000 rs.

Ao porteiro da Câmara

3.966

Ao relojoeiro, de ordenado e 4 alqueires de centeio

12.000

Total

128.296 réis

Total Geral

729.056 réis

Nota - As propinas sem provisão são registadas em itálico. 
Situação semelhante à descrita para a ouvidoria de Beja, quanto aos abusos praticados pelos provedores, se verifica na comarca de Moncorvo, pela mesma época, onde José António de Sá dá conta de excessos e abusos multiplicados, por tais magistrados, com prejuízo do bem comum, dos rendimentos dos concelhos e da terça real, como se pode ver.

- Os salários arbitrários do provedor e seus oficiais absorviam o terço devido aos coimeiros, os quais eram condenados quando apresentavam um pequeno número de coimas. Os provedores incentivavam ao aumento das coimas, uma vez que, quer absolvessem, quer condenassem, sempre cobravam salários.

- Os juízes vinteneiros e almotacés não faziam audências. Todos eles iam à audiência do provedor, os quais decidiam a seu arbítrio, alterando mesmo as posturas das câmaras. Nas audiências da provedoria, aquele magistrado vexava «infalivelmente» os juízes vinteneiros, condenando-os quando estes apresentavam um rol de poucas coimas.

- Como os povos se queixavam dos salários excessivos do provedor e seus oficiais, aquele usava o estratagema de se fazerem pagar, não pelas partes condenadas, mas pelos concelhos. O provedor em funções, Escobar, levava apenas 20 réis das partes pelas coimas apeladas, absorvendo o terço coimeiro e, não sendo este suficiente, ressarcia-se dos bens do concelho, uma vez que, destes, ninguém zelava.

- O provedor tomava contas em muitos livros de acórdãos, vereações e condenações, e rubricava os livros da competência dos corregedores, como os das almotaçarias, acórdãos das câmaras, correições das mesmas e condenações dos almotacés, com o fim de recolher assinaturas.

- O provedor multiplicava os precatórios, não exercitando os seus ofícios por mandados, a fim de ser pago daquelas, pelos concelhos.

- Repetia os registos das leis já mandadas registar pelo corregedor nos conceIhos, duplicando, assim, os gastos destes.

- A receita e despesa das câmaras, em vez de ser lançada nos respectivos livros, de acordo com o modelo apresentado na lei de 23 de Julho de 1766, era exarada, apenas, no fim do ano, pelo escrivão do concelho, à vista dos bilhetes, sem que o tesoureiro do concelho assinasse a receita. Ora, o provedor 
cobrava executivamente os seus salários, obrigando o tesoureiro a pagar do seu bolso, caso não existisse dinheiro no cofre, o que tornava odiosos os lugares de tesoureiro e procurador do concelho.

- O provedor autorizava despesas ilegítimas e violentas, como no concelho de Moncorvo, onde repartia com o corregedor, o juiz de fora e vereadores, grande parte dos rendimentos do município, a título de propinas, mesmo não havendo sobras, a pretexto das procissões, dos salários das vereações - nas aldeias do termo, 14 diários por cada uma, quando só lhe competiam cinco; na sede do concelho, 4000 réis, quando a mesma não durava mais que uma hora; e nas ocasiões faustas e infantas da casa real, cinco moedas de ouro para cada um. Tais práticas, além de prejudicarem as obras urgentes e necessárias do concelho, faziam com que este se encontrasse endividado à fábrica da igreja matriz de Moncorvo, em 1812800 réis, entidade a quem pediam, de empréstimo, as verbas necessárias para serem pagos. Os provedores eram, assim, "destruidores dos rendimentos dos concelhos», admitindo abusos, e levantando a maior parte dos seus rendimentos para si e seus oficiais.

- Dava esmolas das receitas dos concelhos.

- Não observava as regras prescritas no regimento dos contadores das comarcas, efectuando as arrematações das rendas fora dos prazos determinados, com prejuízo da fazenda real, e deixando ao desamparo os bens do concelho, terças, coimas e órfãos.

- O provedor da comarca só podia tomar contas aos concelhos pelo livro da receita e despesa que the era apresentado pelo escrivão da câmara, de acordo, aliás, com o alvará de 17 de Novembro de 1571 e a lei de 23 de Julho de 1766. Por outro lado, determinava a lei de 7 de Novembro de 1750 que os provedores, nas contas que tomassem aos concelhos, cuja receita não ultrapassasse os 50000 réis, levassem 100 réis; 200 réis na receita dos concelhos compreendida entre 50000 e 100000 réis; 400 réis nas receitas entre 100000 e 400 000 réis; e 600 réis a partir daí. De acordo com esta lei, entendia-se ainda que as contas deviam ser tomadas num só livro, devendo separar-se a terça do montante do concelho.

Ora, os provedores de Moncorvo tinham multiplicado uma «infinidade» de livros, nomeadamente os livros das condenações dos povos e vilas, tomando contas separadas em cada um, recebendo dos concelhos tantos emolumentos 
quantas as contas, cobrando salários «injustos» para si, o escrivão, o porteiro, etc., de tal forma que esgotavam financeiramente os concelhos.

Esta abusiva prática, generalizada pelos provedores de Moncorvo no século XVIII, levava a que estes magistrados e seus oficiais de justiça cobrassem de salários quantias muito superiores às receitas exaradas nos livros, chegando a 20000 e 30000 réis, segundo o número das vintenas, e a quantidade e diversidade dos livros introduzidos.

- O provedor, das receitas provenientes das achadas - cujo livro se encontrava nas mãos do escrivão da vila, a quem os juízes dos povos, jurados e couteiros apresentavam as denúncias -, absorvia para si e seus oficiais o terço do concelho e o terço coimeiro que pela lei pertencia ao denunciador, em compensação do seu penoso ofício.

- Nos termos de Moncorvo e Freixo de Espada à Cinta, os provedores consentiam que os juízes vinteneiros arrematassem e guardassem todos os rendimentos das suas aldeias, levando-lhes em conta todas as despesas, que queriam vultuosas e injustas, expondo assim o rendimento dos concelhos e terça real à «delapidação e roubo», uma vez que muitos daqueles juízes ficavam com os referidos dinheiros.

- Na provedoria de Moncorvo todas as despesas se aprovavam, nada se glosando. Como exemplo, Sá apresenta o seu provimento de Moncorvo sobre a extinção das propinas injustas que levavam anualmente os corregedores, provedores, juízes de fora, oficiais de câmara, procurador, alferes da bandeira, porteiro, alcaide, etc., sem haver provisão alguma; e no caso de haver provisão, sem respeitarem a condição de haver as «sobras» requiridas por tais provisões e pelo aviso régio de 1 de Setembro de 1790 .

O abuso tinha chegado a tanto que, até sem provisão, os referidos ministros levavam, do rendimento da câmara de Moncorvo, 24000 e 26000 réis em todas as ocasiões faustas e infaustas da casa real, como constava dos livros respectivos em 1768, 1771, 1774, 1777 e 1781.

- Como as despesas motivadas pelos provedores e seus oficiais com «salários injustos» eram elevadas, acontecia que muitos concelhos não tinham rendimentos disponíveis. Nesses casos, o provedor e seus oficiais eram «embolsados» à custa dos procuradores do concelho, contra quem passavam 
«mandado executivo», transgredindo, assim, o alvará de 4 de Maio de 1646, e fazendo oneroso o ofício de procurador, que ninguém queria servir em tais concelhos.

- Outro abuso da provedoria tinha a ver com salários. Sendo esta matéria tão delicada em direito, em que nenhum magistrado ou oficial de justiça podia levar mais do que expressamente estava definido nas ordenações, leis, alvarás, regimentos, provisões e resoluções régias, Sá mandou executar em toda a sua comarca, por provisão de 6 de Julho de 1792, do Tribunal do Desembargo do Paço, a legislação em vigor sobre tal matéria. Ora, no Juízo da Provedoria de Moncorvo, além dos salários cobrados indevidamente aos concelhos, verificava-se que os salários cobrados pelo provedor eram superiores aos que the competiam.

Por outro lado, os salários dos oficiais de justiça da comarca, de acordo com o regulamento interino mandado fazer pelo Governo e confirmado por provisão real quanto a Moncorvo, exarava que os homens da vara recebiam 400 réis por dia. Ora, o provedor de Moncorvo autorizava que os seus meirinhos da vara recebessem 600 réis por dia, que era o salário taxado para meirinhos gerais, impondo assim, «além do seu», um outro tributo na comarca. ${ }^{(6)}$

Será que estes excessos dizem mais respeito aos provedores que aos corregedores ou juízes de fora, quiçá, porque aqueles, detendo funções de natureza económica mais importantes que estes, mais facilmente podiam fazer-se pagar dos rendimentos e impostos a que superintendiam, das câmaras, ou dos bens de instituições e de particulares que geriam?

São várias as provisões que conhecemos, repreendendo ou limitando os exageros dos provedores, quanto a precatórios e mandados, a aposentadorias que só deviam

(6) José António de Sá, Regimento dos corregedores das comarcas do Reino (1795), códice manuscrito do IANTT, Ministério do Reino, maço 325, em publicação; Abuzos praticados na provedoria de Moncorvo, IANTT, Ministério do Reino, maço 325; Memoria dos abuzos praticados na comarca de Moncorvo, e provimentos do corregedor...(1790), publicada por Fernando de Sousa, A Memória dos abusos praticados na comarca de Moncorvo de José António de Sá (1790), in ob. cit., Porto, 1974. António José de Sá, Dissertação sobre a origem das sociedades civis para servir de preliminar ao tractado dos corregedores das comarcas, IANT, Ministério do Reino, maço 325; Plano de correição que tem seguido o doutor Jozé António de Sá, corregedor na comarca de Moncorvo, IANT, Ministério do Reino, maço 326; Planos do corregedor de Moncorvo e outras informações sobre os abuzos que achou introduzidos naquella comarca, em prejuizo do povo (1790), IANT, Ministério do Reino, maço 326; e, ainda no mesmo maço, Plano de correição. Mappas, e outras fontes manuscritas, da autoria de José António de Sá. 
dar lugar a benefícios em espécie e não em dinheiro, a emolumentos e salários cobrados às partes acima do que estava estabelecido na lei, a rubricas de livros ilegais ou estabelecidas arbitrariamente com o único objectivo de cobrarem dinheiro aos concelhos, etc.. Será por tais razões que os conflitos dos juízes de fora ou dos conceIhos com os provedores parecem ser mais frequentes do que com os corregedores?

Importa perguntar: quais as razões que explicam os abusos, excessos e violências exercidos pelos magistrados, oficiais e câmaras em geral, sobre o povo? E por outro lado, saber: porque é que as classes populares não denunciavam, mais frequente e veementemente as arbitrariedades e irregularidades dos mesmos?

No que diz respeito à primeira questão, as razões têm a ver, entre outras, com o carácter hereditário dos ofícios, com o modo de nomeação dos magistrados e com o montante dos salários auferidos por estes.

A hereditariedade dos ofícios da justiça e fazenda, assente na prática de «darem homens aos ofícios e não os ofícios aos homens», foi anulada pela carta de lei de 23 de Novembro de 1770, na sequência da Lei da Boa Razão. Procurava-se, com tal medida, acabar com o erróneo, abusivo e suposto direito consuetudinário de os ofícios passarem de pais para filhos, independentemente da competência e idoneidade dos oficiais, os quais, a partir de tal diploma, passaram a exercer as suas funções a título precário, dependendo a sua recondução ou continuidade nos cargos, do modo como estes eram exercidos.

Não conhecemos, ainda, quais os efeitos práticos da aplicação desta lei, a nível nacional. Mas sabemos que a sua execução continuou a ser fortemente influenciada pela tradição multissecular da herança dos ofícios e em numerosos casos não cumprida ou iludida.

Por outro lado, muitos bacharéis e ministros, à força de dinheiro, conseguiam ser nomeados, não por consulta mas por despacho, levando, assim, para tais cargos, «a despesa feita antes de ganhada», o que os levava a actuarem de forma a ressarcirem-se das despesas feitas o mais depressa possível. Investidos nas suas funções, tais magistrados examinavam «as causas crimes já findas», levantando uma qualquer formalidade da lei não cumprida, reabrindo os processos e alimentando, desse modo, contendas eternas que desgraçavam os lavradores. ${ }^{(7)}$

Por fim, é preciso não esquecer os salários «mesquinhos e insuficientes» que, como observa Borges Carneiro, eram pagos aos magistrados territoriais, de acordo com a lei de 1750, em finais do Antigo Regime, salários que se mantiveram, pelo menos, até 1820 .

(7) Bacelar Chichorro, fonte cit., publicada por Amzalak. 
Vejamos, a título de exemplo, o caso dos provedores - sabendo nós que os corregedores se debatiam com idêntica situação - , nas vésperas da revolução liberal. Este magistrado, anualmente, ganhava 106666 réis, o que somava, no seu mandato trienal, a verba de 319998 réis. Ora, deste montante, os provedores, em inícios do século XIX, descontavam 28520 réis dos novos direitos, carta e portaria interna; 31999 réis de décima; 17080 réis de emolumentos e selos da carta e portaria; e, finalmente, 31999 réis de rebate de metade do ordenado em papel, a 20\%, o que tudo somava 109598 réis. Isto é, o salário anual de um provedor não era suficiente para cobrir todos os descontos que lhe eram feitos pelo exercício do seu mandato trienal. ${ }^{(8)}$

Ou o caso dos escrivães das diferentes entidades da comarca de Moncorvo, onde, até meados do século XVIII, não auferiam qualquer ordenado, propina ou emolumento. Só a partir da resolução de 12 de Junho de 1750 é que os escrivães da comarca passaram a ter direito a propinas, o que ajuda a explicar as extorsões e abusos praticados e a gerar uma cumplicidade tácita entre magistrados e os seus oficiais que de si dependiam.

Porque é que as denúncias das extorsões e violências eram raras?

A resposta a esta questão prende-se com razões de natureza cultural, como bem observou, já em 1781, Guimarães Moreira. As «castas de vexações», as «opressões públicas» que se faziam ao «miserável povo», muito mais pesadas e violentas que todos os tributos que se cobravam - assevera aquele corregedor -, encontravam-se arreigadas de tal forma que, tanto os opressores como os oprimidos as consideravam naturais. Ninguém se preocupava com aquelas, justamente porque se encontravam identificadas com os «nossos costumes». ${ }^{(9)}$

É certo que os órgãos do governo central, ao longo do século XVIII, através de sucessivas determinações, procuraram conter a rapacidade e a ganância dos magistrados e oficiais territoriais e locais.

E que a Lei da Boa Razão, de 18 de Agosto de 1768, procurou reduzir fortemente o domínio da aplicação dos costumes (como do direito romano e do direito comum), restringindo a sua omnipotência àqueles que estivessem ratificados por assentos da

(8) Manuel Borges Carneiro, Portugal Regenerado, Lisboa, 1820; Parabolas accrescentadas ao Portugal Regenerado, Lisboa 1820; Juizo critico sobre a legislação de Portugal ou Parabola VII accrescentada ao Portugal Regenerado, Lisboa, 1821; Dialogo sobre o futuro destino de Portugal ou Parabola VIII accrescentada ao Portugal Regenerado, Lisboa, 1821.

(9) Demonstração das principais causas com que se têm arruinado a agricultura, indústria e povoação do Reino de Portugal, e os meios com que me parece se pode restabelecer, de autor anónimo e datando, provavelmente, de 1796, publicada por José Luís Cardoso, Memórias económicas inéditas (1780-1808), Lisboa, 1987, p. 101. 
Casa da Suplicação - o que permitia aos corregedores anular ou suspender, por exemplo, as posturas municipais, quando prejudiciais ao bem público.

Mas em finais de Setecentos, como já demonstrámos quanto à comarca de Moncorvo, os «inveterados costumes», fundamentadores da opressão e da rapina sobre o povo, continuavam praticamente intactos e assim se mantiveram durante boa parte do século XIX, no que diz respeito aos provedores, corregedores e câmaras, até à sua extinção em 1834, apesar de o poder central, o rei e o Governo terem perfeito conhecimento do que se passava, uma vez que todas as fontes de que nos servimos para elaborar este trabalho, são relatórios e memórias enviadas ao Governo, existentes nos arquivos centrais.

\section{Conclusão}

«Estes povos distantes da Corte são mais sujeitos ao abuso dos que governam; porque os seus gritos dificultosamente chegam ao trono; por isso é mais perigoso um magistrado que abusa das leis para os seus interesses; e muito mais aquele, a quem nem as ordens da suprema imperante podem servir de barreira».

(José António de Sá, Regimento dos corregedores das comarcas do Reino, 1795)

Através dos exemplos apresentados e de outros que poderíamos aduzir, é possível chegar a algumas conclusões quanto ao exercício do poder local no Portugal de finais do Antigo Regime.

Em primeiro lugar, importa chamar a atenção para a generalização das prepotências, extorsões e abusos praticados pelas câmaras, quer nos municípios de juízes de fora, quer nos municípios de juízes ordinários. Sá garante até que tais abusos eram maiores nas câmaras com magistrados de vara branca do que nas outras.

Juízes de fora, provedores e corregedores, regra geral, adaptam-se aos costumes, ao funcionamento tradicional, ainda que opressivo, das câmaras e percebem que se não levantarem problemas, também beneficiam com as ilegalidades praticadas.

Em segundo lugar, esta realidade permite-nos compreender melhor o esforço que as aristocracias/oligarquias instaladas na governação municipal desenvolvem para se eternizarem no poder. Sabemos já que a governação das câmaras em finais do Antigo Regime, com excepção dos juízes de fora, se encontrava nas mãos de algumas famílias nobres ou enobrecidas, as quais procuravam ciosamente monopolizar os ofícios municipais, afastando, sempre que possível, os representantes de grupos sociais prestigiados ou em ascensão, como acontece na comarca de Moncorvo com os advogados. 
Tal determinação, mais do que por razões de prestígio social, tem a ver sobretudo com razões de natureza económica. Os cargos que esta nobreza de província exercia, embora mal remunerados, além de constituírem fonte de poder, eram rendosos, uma vez que os vereadores e o procurador, com a cumplicidade, mais dos provedores e juiz de fora que dos corregedores, encontravam formas de aumentar consideravelmente propinas e emolumentos, muito significativos se tivermos em atenção os rendimentos das câmaras.

Assim sendo, melhor se pode compreender a situação de endividamento crónico das autarquias, as quais, sem fundos para garantirem as obras e os melhoramentos materiais indispensáveis ao desenvolvimento da economia local e ao bem estar das populações locais, acabam por usar métodos coercivos e abusivos para alargarem as suas receitas.

Finalmente, importa referir que a situação enunciada, a cumplicidade que se pressente a nível local entre provedores, corregedores, juízes de fora e oficiais das câmaras é do conhecimento do Estado, muito particularmente do Governo, o qual nunca efectuou um esforço sério para conter ou limitar as prepotências e vexações exercidas pelas autoridades administrativas e judiciais referidas.

No Portugal de finais do Antigo Regime, os abusos praticados pela administração regional/local - magistrados territoriais, magistrados e oficiais concelhios - tinham, assim, como principais consequências:

- forte redução dos rendimentos dos concelhos, absorvidos em «exorbitantes e injustos salários» e emolumentos, o que levava à acumulação de dívidas por parte dos municípios;

- forte redução do imposto régio designado por terça real;

- criação de novos encargos e de novas formas de cobrança, de forma a aumentar as suas receitas exauridas pela administração local;

- impossibilidade de se fazerem as obras públicas necessárias, obrigando ao lançamento de fintas extraordinárias sobre os povos.

Em suma, num tempo em que as câmaras ainda não tinham descoberto as virtualidades da construção civil, tão em moda no nosso tempo, as prepotências, excessos e abusos praticados constituíam, no fundo, o meio de que as mesmas se serviam para aumentarem, como refere Gervásio Pais «o património de quem entra nelas e de quem as sindica». É por isso que se torna fundamental conhecer e aprofundar esta problemática para melhor se compreender a estrutura e funcionamento da sociedade rural no Portugal de finais do Antigo Regime. 
(Página deixada propositadamente em branco) 
Investigaçāo

Coimbra.

Imprensa da Universidade 